\title{
EVALUASI PENYELENGGARAAN DIKLAT TEKNIS SUBSTANTIF MULTIMEDIA BAGI GURU MADRASAH ALIYAH DI BALAI DIKLAT KEAGAMAAN SEMARANG
}

\author{
Oleh: Ratna Prilianti \\ Balai Diklat Keagamaan Semarang \\ ratna.prilianti@gmail.com
}

\begin{abstract}
ABSTRAK
Penelitian inibertujuanuntukmenentukankepuasan peserta diklat(reaction) terhadap aspek edukatif, aspek fasilitas, aspek pelayanan dan hasil belajar peserta diklat (learning) pada penyelenggaraan Diklat Multimedia bagi Guru Madrasah Aliyah di Balai Diklat Keagamaan Semarang. Penelitian ini merupakan penelitan deskriptif kuantitatif dengan metode survai. Model evaluasi yang digunakan adalah menggunakan model Kirkpatrick. Dalam model Kirkpatrick, evaluasi dilakukan melalui empat level, yaitu reaction, learning, behaviour dan impact. Pada penelitian ini hanya dilakukan untuk evaluasi level 1 dan 2. Kepuasan peserta diklat (reaction) terhadap aspek edukatif penyelenggaraan Diklat Multimedia masuk kategori baik 87.62, aspek fasilitas kategori kategori baik 87.63, dan aspek pelayanan kategori baik 89.38 . Hasil belajar peserta diklat (learning) pada aspek sikap kategori sangat baik 88.54, aspek pengetahuan kategori baik 82.07 dan pada aspek keterampilan kategori sangat baik 85.68. Untuk meningkatkan kepuasan (reaction) peserta diklat pada penyelenggaraan diklat dapat dilakukan dengan meningkatkan frekuensi kegiatan ekstrakurikuler, mengatur menu secara lebih bervariasi dan menggunakan software yang sama antara peserta diklat dan widyaiswara. Hasil belajar (learning) peserta diklat dapat ditingkatkan lagi dengan menggunakan metode tutor sebaya. Evaluasi pelaksanaan diklat perlu dilakukan untuk level 3 (perilaku kerja) dan 4 (dampak) melalui evaluasi pasca diklat.
\end{abstract}

Kata kunci : evaluasi kickpatrick, reaksi, hasil belajar

\section{ABSTRACT}

The aim of this research is to determine the satisfaction of the training participants (reaction) on the educational, facilities, service aspect and learning outcomes of the training participants (learning) at the Multimedia Substantive Technical Training to the Teachers of Islamic High School at the Training Center of the Ministry of Religious Affairs Semarang. This 
research is a quantitative descriptive research with survey method. The evaluation model used is the Kirkpatrick Model. In this model, evaluation is done through four levels, namely: reaction, learning, behavior and impact. In this research only conducted for 1 st and 2nd level of evaluation. The satisfaction of the training participants (reaction) at the educational aspect of multimedia training implementation in good category (87.62), at the facilities aspects in good category (87.63), and at the service aspect in good category (89.38). Meanwhile, Learning outcomes of the training participants (learning) at the attitude aspect in very good category (88.54), at the knowlegde aspect in good category (82.07) and at the skill aspects in very good category (85.68). To increase the satisfy of training participants (reaction) in the training implementation can be done through increase the frequency of extracurricular activities, manage the menu variatively and use the same software between training participants and trainer. Learning outcomes (learning) of the training participants can be improved by using tutor peer method. Evaluation of the training implementation needs to be done at 3rd level (work behavior) and 4th level (impact) through post training evaluation.

Keywords: Kickpatrick evaluation, reaction, learning outcomes

\section{PENDAHULUAN}

Pendidikan suatu investasi yang sangat penting dalam kehidupan suatu bangsa untuk meningkatkan kualitas hidup manusia. Dengan pendidikan, seseorang dapat memperoleh sejumlah pengetahuan dan keterampilan. Untuk itu, pembangunan di bidang pendidikan merupakan bagian yang penting dalam rangka pengembangan dan peningkatan kualitas Sumber Daya Manusia menuju masyarakat mandiri. Dalam hal ini, Pegawai Negeri Sipil yang sekarang disebut Aparatur Sipil Negara (ASN) seiring diterbitkannya Undang-Undang No. 5 Tahun 2014 tentang Aparatur
Sipil Negara memiliki peranan strategis dalam menyelenggarakan tugas-tugas umum pemerintahan dan pembangunan yang sesuai dengan tuntutan zaman terutama untuk menjawab tantangan masa depan.

Untuk mewujudkan tuntutan tersebut diperlukan adanya Aparatur Sipil Negara yang berkualitas. Aparatur yang berkualitas adalah aparatur yang memiliki kecakapan dan kemampuan untuk melaksanakan setiap tugas yang dibebankan kepadanya dengan baik, serta mampu memelihara dan mengembangkan kecakapan dan kemampuannya secara berkesinambungan. Oleh karena 
itu, sudah menjadi tugas pimpinan pada setiap organisasi untuk selalu memikirkan suatu upaya yang harus dilakukan untuk senantiasa memelihara dan membina semua aparatur agar dapat lebih berkualitas dalam rangka pencapaian tujuan organisasi.

Balai Diklat Keagamaan (BDK) merupakan salah satu lembaga yang bertugas meningkatkan mutu pendidikan, salah satunya adalah meningkatkan kualitas pendidikan dan profesionalisme guru. Peningkatan profesionalisme guru dapat dilakukan dengan memberikan kesempatan mengikuti Pendidikan dan Pelatihan (DIKLAT). Di negara-negara maju, diklat menjadi program pokok yang diprioritaskan. Pendidikan dan Pelatihan guru dimaksudkan untuk mendapatkan inovasi dalam proses pembelajaran, sehingga nantinya dapat dijadikan bekal ketika guru mengajar di madrasahnya masingmasing. Upaya untuk Peningkatan mutu pendidikan merupakan salah satu unsur konkrit yang sangat penting dalam upaya peningkatan kualitas sumber daya manusia.

\begin{tabular}{lrr}
\multicolumn{1}{c}{ Dalam kaitan } & tersebut, \\
Wursanto & (1994: & 59) \\
mengemukakan & bahwa untuk \\
mempertinggi & mutur para \\
aparatur, baik pengetahuan, & peterampilan \\
kemampuan, & keteran \\
maupun mentalnya kepada para \\
aparatur perlu diberikan berbagai \\
macam pendidikan dan latihan.
\end{tabular}

Dengan demikian, Aparatur yang pernah mengikuti pendidikan dan pelatihan diharapkan dapat melaksanakan tugasnya dan mampu mengatasi segala kesulitan yang dihadapi, baik yang dihadapi sekarang maupun kesulitan yang akan datang sehingga aparatur termotivasi untuk meningkatkan kinerjanya dan bertanggung jawab dalam bidang masing-masing. Hal ini karena kesungguhan seseorang untuk menghasilkan pekerjaan yang baik dan dapat diandalkan mutunya menunjukkan kinerja yang tinggi.

Namun, kenyataannya dilihat dari aktivitas aparatur yang ada, ditemui adanya kejenuhan aparatur dalam melaksanakan pekerjaan, menurunnya semangat dan gairah kerja, kurangnya kreativitas aparatur atas dampak perkembangan teknologi dan pengetahuan yang relevan dengan pekerjaan, tidak disiplinnya aparatur dan seringnya terjadi kesalahan yang diperbuat dalam melaksanakan tugas, semua itu berimplikasi pada kualitas aparatur khususnya guru madrasah yang dalam penelitian ini akan menjadi subjek kajian.

Jika dilihat dari realitas kondisi madrasah dan sumber daya manusia yang dimiliki oleh mayoritas madrasah di lingkungan kantor wilayah kementerian agama Provinsi Jawa Tengah dan provinsi D.I. Yogyakarta yang 
menjadi wilayah kerja Balai Diklat Keagamaan Semarang saat ini masih sangat membutuhkan guru madrasah yang berkualitas dan memiliki kompetensi yang dipersyaratkan. Diakui atau tidak, kualitas madrasah, baik dari sisi akademik maupun manajerial, mayoritas masih rendah. Dalam konteks ini, peran guru madrasah sangat strategis dan menentukan. Untuk itu, para guru madrasah ditantang untuk benar-benar memiliki kompetensi dan bekerja sesuai dengan tuntutan profesionalitasnya sehingga kehadirannya menjadi dambaan dan harapan madrasah di mana tempat mereka mendidik.

Balai Diklat Keagamaan Semarang sebagai lembaga pendidikan dan pelatihan memiliki posisi yang sangat strategis karena berperan sebagai institusi yang berfungsi meningkatkan kualitas sumber daya manusia aparatur negara, baik itu yang menduduki jabatan fungsional maupun struktural.

Pelaksanaan suatu proses peningkatan kompetensi melalui pendidikan dan pelatihan (diklat) memerlukan evaluasi untuk menunjukkan apakah tujuan telah tercapai. Secara khusus Kirkpatrick mengemukan alasan mengapa suatu pelatihan perlu dievaluasi. Pertama, evaluasi dilakukan untuk mengetahui apakah pelatihan dapat memberikan kontribusi pada pencapaian tujuan-tujuan organisasi atau tidak. Tidak hanya itu, pelatihan juga perlu dievaluasi untuk memutuskan apakah program pelatihan tersebut perlu dilanjutkan atau tidak. Yang terakhir adalah evaluasi pelatihan dilakukan untuk mendapatkan informasi mengenai bagaimana meningkatkan dan mengembangkan program pelatihan yang akan datang. Menurut evaluasi 4 tahap dari Kirkpatrick, pada evaluasi tahap 1 (reaction) dan 2 (learning) akan menghasilkan informasi bagi lembaga diklat tentang penyelenggaraan diklat. Sedangkan evaluasi tahap 3 (behavior) dan 4 (result) menghasilkan informasi yang berpusat pada dampak diklat bagi lembaga diklat yang merupakan kondisi pasca diklat. Pada penelitian ini hanya dilakukan untuk evaluasi pada level 1 yaitu reaksi (reaction).

Berdasarkan uraian yang dikemukakan di atas, peneliti merasa tertarik untuk mengkaji secara empirik dengan mengangkat judul Evaluasi Penyelenggaraan Diklat Teknis Substantif Multimedia bagi Guru Madrasah Aliyah di Balai Diklat Keagamaan Semarang. Penelitian ini merupakan salah satu bentuk evaluasi terhadap penyelenggaraan diklat sehingga dapat dijadikan bahan referensi dalam penyelenggaraan diklat yang lebih baik. Dari deskripsi yang ada latar belakang, 
dapat diformulasikan pokok permasalahannya yaitu: "Bagaimana Hasil Evaluasi Penyelenggaraan Diklat Multimedia Bagi Guru Madrasah Aliyah Di Balai Diklat Keagamaan Semarang?"

Tujuan dari Penelitian ini dilakukan untuk:

1. Menentukan kepuasan peserta diklat(Reaction)terhadapaspek edukatif penyelenggaraan Diklat Multimedia Bagi Guru Madrasah Aliyah Di Balai Diklat Keagamaan Semarang

2. Menentukan kepuasan peserta diklat(Reaction)terhadapaspek fasilitas penyelenggaraan Diklat Multimedia Bagi Guru Madrasah Aliyah Di Balai Diklat Keagamaan Semarang

3. Menentukan kepuasan peserta diklat(Reaction)terhadapaspek pelayanan penyelenggaraan Diklat Multimedia Bagi Guru Madrasah Aliyah Di Balai Diklat Keagamaan Semarang

4. Menentukan hasil belajar peserta diklat (Learning) pada penyelenggaraan Diklat Multimedia Bagi Guru Madrasah Aliyah Di Balai Diklat Keagamaan Semarang.

Evaluasi merupakan suatu proses menyediakan informasi yang dapat dijadikan sebagai pertimbangan untuk menentukan harga dan jasa (the worth and merit) dari tujuan yang dicapai, desain, implementasi dan dampak untuk membantu membuat keputusan, membantu pertanggung jawaban dan meningkatkan pemahaman terhadap fenomena. Menurut rumusan tersebut, inti dari evaluasi adalah penyediaan informasi yang dapat dijadikan sebagai bahan pertimbangan dalam mengambil keputusan (Stufflebeam dan Shinkfield ,1985: 159). Komite Studi Nasional tentang Evaluasi (National Study Committee on Evaluation) dari UCLA (Stark \& Thomas, 1994: 12), menyatakan bahwa evaluasi merupakan suatu proses atau kegiatan pemilihan, pengumpulan, analisis dan penyajian informasi yang dapat digunakan sebagai dasar pengambilan keputusan serta penyusunan program selanjutnya. Selanjutnya, Griffin \& Nix (1991:3) menyatakan "Measurement, assessment and evaluation are hierarchial. The comparison of observation with the criteria is a measurement, the interpretation and description of the evidence is an assessment and the judgement of the value or implication of the behavior is an evaluation". Yang dapat kita artikan pengukuran, penilaian, dan evaluasi bersifat hirarki. Evaluasi didahului dengan penilaian (assessment), sedangkan penilaian didahului dengan pengukuran. Pengukuran diartikan sebagai kegiatan membandingkan hasil pengamatan dengan kriteria, penilaian (assessment) merupakan kegiatan menafsirkan dan mendeskripsikan hasil pengukuran, 
sedangkan evaluasi merupakan penetapan nilai atau implikasi perilaku.

Berdasarkan pendapat di atas dapat disimpulkan bahwa evaluasi merupakan proses yang sistematis dan berkelanjutan untuk mengumpulkan, mendeskripsikan, mengintepretasikan dan menyajikan informasi untuk dapat digunakan sebagai dasar membuat keputusan, menyusun kebijakan maupun menyusun program selanjutnya. Adapun tujuan evaluasi adalah untuk memperoleh informasi yang akurat dan objektif tentang suatu program. Informasi tersebut dapat berupa proses pelaksanaan program, dampak/ hasil yang dicapai, efisiensi serta pemanfaatan hasil evaluasi yang difokuskan untuk program itu sendiri, yaitu untuk mengambil keputusan apakah dilanjutkan, diperbaiki atau dihentikan. Selain itu, juga dipergunakan untuk kepentingan penyusunan program berikutnya maupun penyusunan kebijakan yang terkait dengan program.

Model Kirkpatrick merupakan model evaluasi pelatihan yang memiliki kelebihan karena sifatnya yang menyeluruh, sederhana, dan dapat diterapkan dalam berbagai situasi pelatihan. Menyeluruh dalam arti model evaluasi ini mampu menjangkau semua sisi dari suatu program pelatihan. Dikatakan sederhana karena model ini memiliki alur logika yang sederhana dan mudah dipahami serta kategorisasi yang jelas dan tidak berbelit-belit. Sementara dari sisi penggunaan, model ini bisa digunakan untuk mengevaluasi berbagai macam jenis pelatihan dengan berbagai macam situasi. Dalam model Kirkpatrick, evaluasi dilakukan melalui empat level,yaitu:

1) Level 1 reaction (reaksi)

Evaluasi di level1 bertujuan untuk mengukur tingkat kepuasan peserta pelatihan terhadap penyelenggaraan diklat.Kualitas proses atau pelaksanaan suatu pelatihan dapat diukur melalui tingkat kepuasan pesertanya. Kepuasan peserta terhadap penyelenggaraan atau proses suatu diklat akan berimplikasi langsung terhadap motivasi dan semangat belajar peserta dalam pelaksanaan diklat. Pada penelitian ini, reaksi peserta diklat yang dievaluasi adalah dari aspek edukatif, aspek fasilitas dan aspek pelayanan panitia terhadap peserta diklat.

2) Level 2 learning (belajar)

Evaluasi dilevel 2 bertujuan untuk mengukur tingkat pemahaman peserta terhadap materi diklat atau sejauh mana daya serap peserta program diklat pada materi diklat yang telah diberikan. Program diklat dikatakan berhasil ketika aspek tersebut mengalami perbaikan dengan membandingkan hasil 
evaluasi sebelum dan sesudah pelatihan.

3) Level3 behaviour (perilaku kerja)

Evaluasi di level 3 bertujuan untuk mengukur perubahan perilaku kerja peserta diklat setelah mereka kembali ke dalam lingkungan kerjanya. Perilaku yang dimaksud di sini adalah perilaku kerja yang ada hubungannya langsung dengan materi yang disampaikan pada saat diklat. Evaluasi perilaku ini dapat dilakukan melalui observasi langsung ke dalam lingkungan kerja peserta atau kuesioner. $\mathrm{Di}$ samping itu bisa juga melalui wawancara dengan atasan maupun rekan kerja peserta.

4) Level 4 impact (dampak)

Evaluasi di level 4 bertujuan untuk mengetahui dampak perubahan perilaku kerja peserta pelatihan terhadap tingkat produktifitas perusahaan. Aspek yang bisa menjadi acuan dalam evaluasi ini meliputi kenaikan produksi, peningkatan kualitas produk, penurunan biaya, penurunan angka kecelakaan kerja baik kualitas maupun kuantitas, penurunan turn over,maupun kenaikan tingkat keuntungan.

Pada penelitian ini peneliti hanya melakukan evaluasi penyelenggaraan diklat pada level
1 dan level 2 yang datanya dapat diambil selama peserta berada di kampus Balai Diklat Keagamaan Semarang pada tanggal 15 sampai dengan 24 Agustus 2016. Menurut Kirkpatrick's, Level of Evaluation pendapat peserta diklat pada evaluasi tahap 1 atau tahap reaksi lebih merupakan umpan balik bagi narasumber/widyaiswara/ fasilitator dan organisasi penyelenggaran diklat. Dalam The Cadanian Journal of Program Evaluation dijelaskan bahwa level 1 "reaction" dari evaluasi Kirkpatrick sering disebut sebagai "happy face evaluation" yang mengukur reaksi peserta dan kepuasan mengikuti diklat dan proses pembelajaran. Reaction level mengevaluasi terhadap reaksi peserta pelatihan berarti mengukur kepuasan peserta (customer satisfaction). Program pelatihan dianggap efektif apabila proses training dirasa menyenangkan dan memuaskan bagi peserta pelatihan sehingga mereka tertarik dan termotivasi untuk belajar dan berlatih. Dari hasil penelitian Sopacua dan Budijanto dijelaskan bahwa peserta akan termotivasi apabila proses pelatihan berjalan memuaskan bagi peserta yang pada akhirnya akan memunculkan reaksi dari peserta yang menyenangkan. Sebaliknya, apabila peserta tidak merasa puas terhadap proses pelatihan yang diikutinya maka mereka tidak akan termotivasi untuk mengikuti kegiatan pelatihan lebih lanjut. 
Untuk evaluasi level 3 dan 4 tidak diteliti untuk karena disebabkan alasan waktu pengambilan data haruslah setelah peserta diklat selesai melaksanakan diklat dan kembali ke unit kerjanya masing-masing. Namun, Balai Diklat Keagamaan Semarang sudah berusaha untuk melakukan evaluasi pada level 3 dan level 4 dengan melakukan kegiatan evaluasi pasca diklat untuk melihat perubahan perilaku kerja alumni diklat dan dampaknya terhadap unit kerja masing-masing alumni.

Pengertian diklat berdasarkan PMA no. 75 Tahun 2015 adalah penyelenggaraan pembelajaran dan pelatihan dalam rangka mengembangkan kompetensi pegawai sesuai persyaratan jabatan masing-masing pada kementerian agama yang dilaksanakan paling sedikit 40 (empat puluh) jam pelajaran, dengan durasi tiap jam pelajaran 45 (empat puluh lima) menit.

Pelaksanaan Diklat Multimedia bagi guru Madrasah Aliyah ini termasuk dalam diklat teknis susbtantif. Diklat teknis subtantif merupakan diklat yang diselenggarakan untuk memberikan pengetahuan dan ketrampilanyang bersifat substantif dalam rangka pencapaian kompetensi yang terkait dengan pekerjaan yang bersangkutan, sehingga mampu melaksanakan tugas dan tanggungjawabnya secara profesional.

\section{METODE PENELITIAN}

1. Metode Penelitian

Penelitian ini merupakan penelitan deskriptif kuantitatif dengan metode survai. Kerlinger dalam Sugiono (2001: 79) mengemukakan bahwa penelitian survei adalah penelitian yang dilakukan pada populasi yang besar maupun kecil, tetapi yang dipelajari adalah data dari sampel yang diambil dari populasi tersebut, sehingga ditemukan kejadian relatif, distribusi dan hubungan antar variabel.

\section{Sasaran Penelitian}

Penelitian ini dilaksanakan di Balai Pendidikan dan Pelatihan Keagamaan Semarang khususnya pada kegiatan Diklat Teknis Substantif Multimedia bagi Guru Madrasah Aliyah yang dilaksanakan selama 10 hari. Peserta diklat adalah para guru madrasah aliyah di lingkungan kerja Balai Diklat Keagamaan Semarang yaitu Kantor Wilayah Kementerian Agama Provinsi Jawa Tengah dan Provinsi D.I. Yogyakarta.

Jumlah peserta diklat sebanyak 30 orang guru yang mendeskripsikan tingkat kepuasan peserta terhadap aspek edukatif, kurikulum dan pelayanan panitia pada Diklat Teknis Teknis Substantif Multimedia bagi Madrasah Aliyah dengan menyebarkan quesioner berupa angket. Untuk mengetahui hasil belajar peserta diklat 
menggunakan tes tertulis berupa pre dan post test, penilaian sikap menggunakan lembar pengamatan dan ketrampilan menggunakan unjuk kerja.

\section{Teknik Pengumpulan Data}

Instrumen atau alat yang digunakan dalam penelitian ini bertujuan untuk memperoleh data yang sesuai dengan objek pembahasan yang dikemukakan adalah dengan menggunakan angket dengan jawaban tertutup. Dalam upaya mengumpulkan data sebagai dasar analisis untuk menjawab permasalahan yang telah dirumuskan sebelumnya, dilakukan dengan teknik:

a. Angket merupakan teknik pengumpulan data yang dilakukan dengan cara memberi seperangkat pertanyaan atau pernyataan tertulis kepada responden untuk dijawab secara tertulis pula. Jumlah item angket untuk kepuasan peserta aspek edukatif sebanyak 4 item pertanyaan, aspek fasilitas 9 item dan aspek pelayanan 5 item yang kemudian dinilai dengan menggunakan Penilaian Acuan Patokan sehingga dapat ditentukan kategori dari jawaban responden.

Presentase Kepuasan $=\frac{\sum \text { skor perolehan }}{\sum \text { skor maksimal }} \times 100$
Tabel 1. Rentang Penilaian Acuan Patokan

\begin{tabular}{cll}
\hline NO & RENTANG & SEBUTAN \\
\hline 1 & $86,68-100$ & Baik \\
\hline 2 & $73,34-86,67$ & Sedang \\
\hline 3 & $60-73,33$ & Cukup \\
\hline 4 & Kurang dari 60 & Kurang \\
\hline
\end{tabular}

b. Observasi, dilakukan untuk mengumpulkan data-data pendukung untuk mengetahui sikap peserta diklat selama kegiatan diklat berlangsung.

c. Tes tertulis, dilakukan untuk mengumpulkan data terkait dengan hasil peserta diklat berupa pengetahuan yang dilaksanakan sebelum penyelenggaraan diklat (pretest) dan setelah penyelenggaran diklat (post test)

d. Kinerja dilakukan untuk mengumpulkan data terkait hasil peserta diklat yang berupa keterampilan peserta diklat.

e. Dokumentasi, dilakukan untuk mengumpulkan datadata tertulis seperti dokumen penyelenggaraan diklat seperti data peserta diklat, data widyaiswara, panitia, laporan persiapan dan pembukaan diklat dan kelengkapan berkas lainnya. 
Dalam evaluasi program diklat diperlukan standar penilaian sesuai kategori seperti yang tecantum pada Surat Keputusan Kepala Badan Litbang dan Diklat Nomor 60 Tahun 2012 tentang Standar Kediklatan Teknis Kementerian Agama menyatakan bahwa peserta diklat dapat dinyatakan:

a. Sangat baik jika nilai $\geq 86$,

b. Baik jika nilai $76-85$,

c. Cukup jika nilai $66-75$,

d. Kurang jika nilai $56-65$,

e. Kurang sekali jika nilai $\leq 55$

Peserta diklat dinyatakan lulus jika rata-rata minimal 76 dengan kategori baik. Peserta diklat yang nilainya dibwah 76 akan mendapat surat keterangan telah mengikuti diklat (Diklat, 2012).

\section{Teknik analisis data}

Berdasarkan permasalahan dan tujuan penelitian ini, maka teknik analisis data yang digunakan dalam penelitian ini adalah analisis deskriptif kuantitatif. Analisis ini digunakan untuk mendeskripsikan tingkat kepuasan peserta diklat terhadap penyelenggaraan Diklat Teknis Substantif Multimedia bagi Guru Madrasah Aliyah yang meliputi aspek edukatif, fasilitas dan pelayanan panitia. Analisis kuantitatif juga digunakan untuk mengetahui hasil belajar peserta diklat baik dari aspek sikap, pengetahuan ataupun keterampilan.

\section{TEMUAN DAN PEMBAHASAN}

1. Kepuasan Peserta Diklat (Reaction) Terhadap Aspek Edukatif

Tabel 2. Kepuasan Peserta Diklat (Reaction) terhadap Aspek Edukatif

\begin{tabular}{|c|l|c|}
\hline No & Uraian & Presentase \\
\hline 1. & Jadwal diklat & 87,90 \\
2. & Materi diklat & 88,03 \\
3. & Manfaat Materi & 88,40 \\
& diklat & \\
4. & ekstrakurikuler & 86,13 \\
\hline & Rata-rata & 87,62 \\
\hline
\end{tabular}

Hasil kepuasan peserta diklat terhadp aspek edukatif dapat dilihat dari hasil yang telah disajikan dalam tabel 2. Aspek edukatif penyelenggaraan diklat merupakan aspek penyelenggaraan diklat yang terdiri dari unsur jadwal diklat, materi diklat, manfaat materi diklat, dan kegiatan ekstrakurikuler pada Diklat Teknis Substantif Multimedia bagi Guru Madrasah Aliyah.

Dari hasil angket yang diedarkan ke peserta diklat terhadap aspek kurikulum dapat dilihat untuk aspek jadwal diklat, materi diklat dan manfaat materi diklat dalam kategori baik $(86,68$ 100) dan untuk ekstrakurikuler dalam kategori sedang (73,3486,67). Secara rata-rata dapat kita ketahui kepuasan peserta diklat terhadap aspek edukatif dalam kategori sedang dengan nilai 87,62. 
Peserta diklat menyatakan baik untuk tiga aspek dalam kurikulum karena menurut peserta diklat materi yang disampakan sangatlah bermanfaat bagi guru-guru peserta diklat teknis substantif multimedia bagi guru madrasah aliyah. Materi pembelajaran inti terdiri dari tujuh mata diklat, yaitu (1) Arabic Enabled yang materinya terdiri dari LEVEL 1 : Aktivasi Arabic : Language Bar, LEVEL 2 : mengatur otomatisasi bahasa, LEVEL 3 : otomatis font dan mengatur Arabic di Android; (2) Program aplikasi presentasi dari MS. Office yang materinya membuka aplikasi, menyimpan, membuat slide master, mengatur design, transition, dan animasi, insert picture, sound dan movie, membuat scroll bar, menyisipkan video flash; (3) Program aplikasi presentasi dari MS. Office dengan materi template presentasi dengan slide master, hyperlink, menyisipkan banyak foto, menyisipkan video dari You Tube dan pembuatan soal dengan triger; (4) Program aplikasi MS. Publiser dengan materi template MS Pubhliser, menumenu Publisher, mengaktifkan MS. Publisher, membuat file Publisher, menyimpan file Publisher, membuka file Publisher, membuat kalender dan kartu nama; (5) Internet sebagai Media Pembelajaran; (6) Penyuntingan Slide; dan (7) Aplikasi Penilaian Kurikulum 2013.

Kegiatan ekstrakurikuler dinyatakan peserta dalam kategori sedang, hal ini kemungkinan dikarenakan kegiatan ekstrakurikuler yang berupa senam pagi di Balai Diklat Keagamaan Semarang hanya dilakukan seminggu sekali, yaitu pada hari Jum'at. Kegiatan senam pagi yang hanya difasilitasi seminggu sekali bagi peserta frekuensinya terlalu sedikit. Fasilitas fitnes dan olahraga lainnya (bola pingpong, bulutangkis dan tenis lapangan) yang ada di Balai Diklat Keagamaan Semarang sudah tersedia, namun kelengkapannya sudah tidak maksimal. Fasilitas fitnes ada yang sudah rusak, jumlah bed pingpong, raket bulutangkis, raket tenis lapangan beserta bolanya yang terbatas jumlahnya, sehingga peserta menyatakan untuk kegiatan ekstrakurikuler dalam kategori sedang.

Kelancaran

pembelajaran dipengaruhi dengan keseragaman software yang digunakan oleh peserta untuk memudahkan pada saat widyaiswara/narasumber menjelaskan mata diklat tertentu. Sebagai contoh pada saat menjelaskan microsoft powerpoint dengan master slide karena microsoft office yang diguanakan berbeda tampilan menu yang ditampilkan juga berbeda. Perbedaaan tampilan di layar LCD milik widyaiswara/ narasumber dengan peserta diklat menyebabkan kelancaran proses belajar mengajar mengalami 
sedikit gangguan. Oleh Karena itu, perlu diseragamkan software yang digunakan oleh widyaiswara dan peserta, yang dapat dideskripsikan dalam surat edaran.

\section{Kepuasan Peserta Diklat (Reaction) Terhadap Aspek Fasilitas}

Tabel 3. Kepuasan Peserta Diklat (Reaction) terhadap Aspek Fasilitas

\begin{tabular}{|l|l|c|}
\hline No & Uraian & Presentase \\
\hline \multirow{2}{*}{1.} & Akomodasi & 88,28 \\
& a. Kebersihan & 88,27 \\
& b. Kenyamanan & 88,30 \\
\hline 2. & Konsumsi & 86,10 \\
& a. Menu & 86,77 \\
& b. Penyajian & 86,20 \\
& c. Higienis & 85,33 \\
\hline 3. & Sarana Diklat & 88,49 \\
& a. Ruang Kelas & 89,50 \\
& b. Alat Bantu & 88,77 \\
& c. Bahan Belajar & 88,83 \\
& d. Asrama & 86,87 \\
\hline & Rata-rata & 87,63 \\
\hline
\end{tabular}

Hasil kepuasan peserta diklat (reaction) terhadap aspek fasilitas pada diklat ini, dapat dilihat pada tabel 3 di atas. Aspek fasilitas penyelenggaraan diklat merupakan aspek penyelenggaraan diklat yang terdiri dari unsur jadwal akomodasi, konsumsi dan sarana kediklatan pada Diklat Teknis Substantif Multimedia bagi Guru Madrasah Aliyah.
Kepuasan peserta diklat terhadap aspek fasilitas unsur akomodasi dam sarana diklat dinyatakan oleh peserta dalam kategori baik dan pada unsur konsumsi pada kategori sedang. Unsur akomodasi peserta yang terdiri dari kebersihan dan kenyamanan diyatakan 88,28 oleh responden, yang artinya masuk dalam kategori baik. Kebersihan dan kenyamanan yang dinilai oleh peserta diklat sebagai responden adalah kebersihan dan kenyamanan baik di asrama maupun di dalam ruang kelas. Sarana kediklatan dinilai 88,49 oleh responden yang berarti dalam kategori baik. Sarana kediklatan di dalam kelas dinyatakan peserta baik karena ketika peserta diklat menemukan kesulitan dalam mengikuti proses pembelajaran langsung ditayangkan di layar LCD dengan berbantuan wps dongle, sehingga kesulitan-kesulitan dapat langsung dipecahkan langsung baik oleh widyaiswara ataupun sesama peserta.

Unsur konsumsi dari aspek fasilitas dinilai oleh responden dengan presentase sebesar 86,10 atau dalam kategori sedang. Menu konsumsi dinyatakan peserta dengan prosentase 86,77 ; penyajian konsumsi 86,20 dan higienis 85,33 . Dari hasil evaluasi terhadap aspek fasilitas unsur konsumsi perlu ditingkatkan dalam hal variasi menu konsumsi dengan mempertimbangkan 
keseimbangan kandungan karbohidrat, protein, lemak, protein dan vitamin. Penyajian konsumsi juga perlu ditata ulang agar menarik, serta higienitas perlu lebih ditingkatkan termasuk kebersihan alat-alat makannya.

\section{Kepuasan Peserta Diklat (Reaction) Terhadap Aspek Pelayanan}

Tabel 4. Kepuasan Peserta Diklat (Reaction) Terhadap Aspek Pelayanan

\begin{tabular}{|c|l|c|}
\hline No & \multicolumn{1}{|c|}{ Uraian } & Presentase \\
\hline 1. & Pelayanan & 89,50 \\
2. & $\begin{array}{l}\text { Kerjasama dengan } \\
\text { Peserta }\end{array}$ & 90,37 \\
3. & $\begin{array}{l}\text { Pelayanan } \\
\text { terhadap }\end{array}$ & 88,43 \\
4. & $\begin{array}{l}\text { Narasumber } \\
\text { Sikap terhadap } \\
\text { Peserta } \\
\text { Kedisiplinan } \\
\text { panitia }\end{array}$ & 90,27 \\
\hline & Rata-rata & 88,33 \\
\hline
\end{tabular}

Hasil kepuasan peserta diklat (reaction) terhadap aspek pelayanan dapat dilihat pada tabel 4 hasil penelitian di atas. Aspek fasilitas pelayanan diklat merupakan aspek penyelenggaraan diklat yang terdiri dari unsur pelayanan terhadap peserta, kerjasama dengan peserta, pelayanan terhadap narasumber, sikap terhadap peserta dan kedisiplinan panitia pada Diklat Teknis Substantif Multimedia bagi Guru Madrasah Aliyah.
Secara keseluruhan responden yang seluruhnya adalah peserta diklat menyatakan bahwa pelayanan terhadap peserta dalam kategori baik dengan nilai rata-rata 89,38 .

\section{Hasil Belajar Peserta Diklat (Learning)}

Hasil belajar dipandang sebagai dua sisi, yaitu sisi peserta diklat dan sisi widyaiswra. Dari sisi peserta, diklat belajar merupakan tingkat perkembangan mental yang lebih baik bila dibandingkan pada saat sebelum belajar. Tingkat perkembangan mental tersebut terwujud pada jenis-jenis ranah kognitif, afektif, dan psikomotorik. Sedangkan dari sisi widyaiswra, hasil belajar merupakan saat terselesaikannya bahan pelajaran (Hamalik, 2006). Hasil belajar adalah kemampuan-kemampuan yang dimiliki peserta didik setelah ia menerima pengalaman belajarnya. Dijelaskan bahwa Horward Kingsley membagi tiga macam hasil belajar, yakni (a) keterampilan dan kebiasaan, (b) pengetahuan dan pengertian, (c) sikap dan citacita. Masing-masing hasil belajar dapat diisi dengan bahan yang telah ditetapkan dalam kurikulum. Dalam sistem pendidikan nasional, rumusan tujuan pendidikan baik tujuan kurikulum maupun tujuan instruksional menggunakan klasifikasi hasil belajar dari Benyamin Bloom yang secara garis 
besar membaginya menjadi tiga ranah, yaitu ranah kognitif, ranah efektif, dan ranah psikomotorik. (Sudjana, 2005).

Pada penelitian ini, Hasil belajar peserta diklat (learning) tidak hanya diukur dari aspek kognitif atau pengetahuan saja, namunjuga mengukur proses belajar peserta diklat pada saat pelaksanaan kegiatan diklat berlangsung, yaitu hasil belajar peserta diklat dari aspek sikap yaitu kerjasama, disiplin, tanggung jawab dan keaktifan serta hasil belajar peserta diklat dari aspek ketrampilan yang dapat diukur dari tugas individu dan tugas kelompok.

\section{A. Hasil Belajar Peserta Diklat (Learning) Aspek Sikap}

Tabel 5. Hasil Belajar Peserta Diklat (learning) Aspek Sikap

\begin{tabular}{|c|c|c|c|c|c|}
\hline \multirow[b]{2}{*}{ Nama } & \multicolumn{4}{|c|}{ Nilai Sikap } & \multirow{2}{*}{$\begin{array}{l}\text { Rata- } \\
\text { rata }\end{array}$} \\
\hline & $\begin{array}{l}\text { Kerja } \\
\text { sama }\end{array}$ & $\begin{array}{c}\text { Disip- } \\
\text { lin }\end{array}$ & $\begin{array}{l}\text { Tangg } \\
\text { jawab }\end{array}$ & $\begin{array}{c}\text { Ke- } \\
\text { aktifan }\end{array}$ & \\
\hline $\mathrm{X} 1$ & 88,17 & 88,50 & 89,00 & 88,50 & 88,54 \\
\hline $\mathrm{X} 2$ & 88,33 & 88,50 & 88,83 & 89,00 & 88,67 \\
\hline X3 & 88,50 & 88,33 & 89,17 & 88,83 & 88,71 \\
\hline$X 4$ & 88,33 & 88,67 & 89,17 & 88,83 & 88,75 \\
\hline$\times 5$ & 88,17 & 88,33 & 88,67 & 88,50 & 88,42 \\
\hline X6 & 89,00 & 88,83 & 89,67 & 90,33 & 89,46 \\
\hline $\mathrm{X7}$ & 90,17 & 87,83 & 91,00 & 89,50 & 89,63 \\
\hline$x 8$ & 89,67 & 87,67 & 89,83 & 89,50 & 89,17 \\
\hline$\times 9$ & 89,67 & 87,83 & 90,00 & 88,17 & 88,92 \\
\hline
\end{tabular}

\begin{tabular}{|l|l|l|l|l|l|}
\hline X10 & 89,67 & 88,00 & 90,17 & 89,17 & 89,25 \\
\hline X11 & 90,67 & 88,00 & 90,50 & 90,00 & 89,79 \\
\hline X12 & 89,00 & 88,67 & 89,83 & 90,67 & 89,54 \\
\hline X13 & 90,00 & 88,83 & 89,50 & 89,83 & 89,54 \\
\hline X14 & 89,33 & 86,83 & 89,33 & 89,33 & 88,71 \\
\hline X15 & 88,67 & 86,83 & 89,17 & 89,17 & 88,46 \\
\hline X16 & 88,33 & 87,83 & 89,50 & 90,00 & 88,92 \\
\hline X17 & 89,50 & 87,83 & 89,33 & 88,17 & 88,71 \\
\hline X18 & 88,67 & 88,67 & 89,50 & 89,50 & 89,08 \\
\hline X19 & 89,67 & 88,83 & 89,67 & 88,17 & 89,08 \\
\hline X20 & 90,33 & 88,67 & 89,33 & 89,50 & 89,46 \\
\hline X21 & 89,00 & 87,67 & 89,00 & 87,83 & 88,38 \\
\hline X22 & 91,17 & 89,67 & 91,33 & 91,50 & 90,92 \\
\hline X23 & 89,83 & 89,17 & 90,83 & 91,17 & 90,25 \\
\hline X24 & 89,50 & 89,00 & 90,33 & 88,17 & 89,25 \\
\hline X25 & 89,83 & 88,67 & 89,50 & 90,67 & 89,67 \\
\hline X26 & 89,00 & 87,17 & 89,50 & 89,17 & 88,71 \\
\hline X27 & 89,50 & 88,50 & 89,17 & 89,00 & 89,04 \\
\hline X28 & 89,17 & 88,67 & 89,67 & 88,50 & 89,00 \\
\hline X29 & 90,33 & 89,17 & 91,00 & 89,83 & 90,08 \\
\hline X30 & 89,00 & 87,83 & 89,50 & 88,67 & 88,75 \\
\hline $\begin{array}{l}\text { Rata- } \\
\text { rata }\end{array}$ & 88,17 & 88,50 & 89,00 & 88,50 & 88,54 \\
\hline
\end{tabular}

Hasil learning aspek sikap dalam penelitian ini dapat dilihat hasilnya pada tabel 5. Aspek sikap peserta diklat yang diamati dengan menggunakan teknik observasi adalah sikap kerjasama, disiplin, tanggung jawab dan keaktifan peserta selama mengikuti pembelajaran di dalam kelas. Proses observasi dilakukan oleh widyaiswara dan para panitia 
pendamping yang mendampingi saat proses belajar mengajar berlangsung.

Dalam proses pelaksanaan dilakukan penilaian sikap peserta didik setiap mata diklat. Widayaiswara melakukan penilaian sikap kerjasama, disiplin, tanggung jawab dan keaktifan selama kegiatan dilakukan baik secara idividu maupun kelompok. Dari 4 indikator sikap yang paling menonjol adalah tanggungjawab dengan nilai rata-rata 89. Hal ini menunjukkan rasa antuasias peserta diklat dalam mengikuti pembelajaran. Sikap disiplin ditunjukkan dengan kehadiran peserta diklat yang tepat waktu, sikap kerjasama ditunjukkan dengan adanya pembimbingan dengan rekan sejawat. Langkah yang dilakukan oleh widyaiswara adalah mengidentifikasi kemampuan awal peserta diklat dalam penguasaan IT heterogen, ada yang kemampuan ITnya sudah menguasai tetapi ada yang belum menguasai. Sehingga pada saat proses pembelajaran adanya kelebihan dan kekurangan peserta diklat dapat digunakan sebagai modal pembelajaran berbasis tutor sebaya. Peserta diklat yang memiliki kemampuan IT bagus ada 8 orang, sehingga pembagian kelompok peserta diklat sebanyak 8 kelompok dengan masingmasing kelompok dipimpin oleh ketua kelompok yang memilki penguasaan IT cukup bagus.
Pembagian kelompok peserta dengan model seperti ini sangatlah membantu kelancaran proses pembelajaran selama kegiatan diklat multimedia ini berlangsung. Sikap tanggungjawab ditunjukkan dengan pengumpulan tugas-tugas secara keseluruhan.

\section{B. Hasil Belajar Peserta Diklat (Learning) Aspek Pengetahuan}

Tabel 6. Hasil Belajar Peserta Diklat (learning) Aspek Pengetahuan

\begin{tabular}{|c|c|c|}
\hline \multirow{2}{*}{ Nama } & \multicolumn{2}{|c|}{ Hasil } \\
\cline { 2 - 3 } & Pre Test & Post Test \\
\hline X1 & 38,00 & 80,00 \\
\hline X2 & 62,00 & 84,00 \\
\hline X3 & 56,00 & 84,00 \\
\hline X4 & 78,00 & 80,00 \\
\hline X5 & 42,00 & 80,00 \\
\hline X6 & 42,00 & 84,00 \\
\hline X7 & 56,00 & 84,00 \\
\hline X8 & 76,00 & 90,00 \\
\hline X9 & 62,00 & 86,00 \\
\hline X10 & 68,00 & 78,00 \\
\hline X11 & 72,00 & 84,00 \\
\hline X12 & 68,00 & 88,00 \\
\hline X13 & 66,00 & 72,00 \\
\hline X14 & 52,00 & 76,00 \\
\hline X15 & 44,00 & 78,00 \\
\hline X16 & 48,00 & 76,00 \\
\hline
\end{tabular}




\begin{tabular}{|l|l|l|}
\hline X17 & 66,00 & 80,00 \\
\hline X18 & 48,00 & 88,00 \\
\hline X19 & 58,00 & 78,00 \\
\hline X20 & 56,00 & 88,00 \\
\hline X21 & 60,00 & 80,00 \\
\hline X22 & 68,00 & 82,00 \\
\hline X23 & 56,00 & 84,00 \\
\hline X24 & 76,00 & 78,00 \\
\hline X25 & 68,00 & 82,00 \\
\hline X26 & 36,00 & 78,00 \\
\hline X27 & 64,00 & 78,00 \\
\hline X28 & 76,00 & 90,00 \\
\hline X29 & 42,00 & 80,00 \\
\hline X30 & 66,00 & 92,00 \\
\hline Rata-rata & 59,00 & 82,07 \\
\hline
\end{tabular}

sebesar 23.09. Dengan demikian hasil belajar peserta diklat dalam aspek pengetahuan mengalami kenaikan yang signifiikan. Seluruh peserta diklat dinyatakan lulus dari diklat Teknis Substantif Multimedia bagi Guru Madrasah Aliyah. Hal ini disebabkan karena hasil belajar peserta diklat (learning) aspek pengetahuan, sikap dan ketrampilan rata-rata lebih dari 76.

\section{Hasil Belajar Peserta Diklat (Learning) Aspek Ketrampilan}

Tabel 7. Hasil Belajar Peserta Diklat (learning) Aspek

Keterampilan

Hasil learning aspek pengetahuan dalam penelitian ini dapat dilihat hasilnya pada tabel 6 dalam hasil penelitian di atas, sebelum pembelajaran dimulai dilakukan pre test sebagai tes awal penjajagan kompetensi guru tentang Kompetensi Multimedia. Setelah akhir pembelajaran dilakukan evaluasi dengan tes tertulis sebagai hasil kemampuan peserta diklat selama mengikuti proses pembelajaran. Dari hasil tersebut terdapat peningkatan hasil dari tes awal yang semula rata-ratanya hanya 59,00 dalam kategori kurang pada pelaksanaan tes akhir meningkat dengan nilai rata-rata 82.09 dalam kategori baik. Peningkatan rata-rata hasil pretest dan posttest adalah

\begin{tabular}{|c|c|c|}
\hline \multirow{2}{*}{ Nama } & \multicolumn{2}{|c|}{ Hasil } \\
\cline { 2 - 3 } & $\begin{array}{c}\text { Tugas } \\
\text { Individu }\end{array}$ & $\begin{array}{c}\text { Tugas } \\
\text { Kelompok }\end{array}$ \\
\hline X1 & 84,60 & 85,00 \\
\hline X2 & 87,60 & 88,33 \\
\hline X3 & 81,80 & 83,33 \\
\hline X4 & 88,20 & 83,33 \\
\hline X5 & 82,00 & 86,67 \\
\hline X6 & 88,20 & 85,00 \\
\hline X7 & 87,40 & 86,67 \\
\hline X8 & 88,60 & 85,00 \\
\hline X9 & 87,60 & 83,33 \\
\hline X10 & 86,40 & 83,33 \\
\hline X11 & 83,60 & 86,67 \\
\hline X12 & 87,60 & 88,33 \\
\hline X13 & 87,60 & 85,00 \\
\hline X14 & 85,60 & 86,67 \\
\hline
\end{tabular}




\begin{tabular}{|l|l|l|}
\hline X15 & 86,60 & 85,00 \\
\hline X16 & 85,60 & 83,33 \\
\hline X17 & 84,40 & 86,67 \\
\hline X18 & 84,40 & 85,00 \\
\hline X19 & 86,60 & 85,00 \\
\hline X20 & 87,40 & 83,33 \\
\hline X21 & 85,00 & 83,33 \\
\hline X22 & 89,60 & 86,67 \\
\hline X23 & 87,80 & 86,67 \\
\hline X24 & 85,40 & 86,67 \\
\hline X25 & 85,60 & 85,00 \\
\hline X26 & 85,20 & 81,67 \\
\hline X27 & 86,40 & 85,00 \\
\hline X28 & 88,40 & 83,33 \\
\hline X29 & 86,20 & 86,67 \\
\hline X30 & 86,00 & 83,33 \\
\hline Rata-rata & $\mathbf{8 6 , 2 5}$ & $\mathbf{8 5 , 1 1}$ \\
\hline
\end{tabular}

Hasil learning aspek ketrampilan dalam penelitian ini dapat dilihat hasilnya pada tabel 5 dalam hasil penelitian di atas. Hasil belajar peserta diklat (learning) aspek ketrampilan dinilai pada saat peserta diklat multimedia mengerjakan penugasan dari para widyaiswara baik tugas yang dilakukan secara individu atau penugasan yang dilakukan secara berkelompok. Penugasan yang dilakukan secara individu adalah untuk mata diklat (1) Arabic Enabled yang materinya terdiri dari LEVEL 1 : Aktivasi Arabic: Language Bar, LEVEL 2 : mengatur otomatisasi bahasa, LEVEL 3 : Otomatis font dan mengatur Arabic di Android; (2) Program aplikasi presentasi dari MS. Office yang materinya membuka aplikasi, menyimpan, membuat slide master, mengatur design, transition, dan animasi, insert picture, sound dan movie, membuat Scroll Bar, menyisipkan Video Flash; (3) Program aplikasi presentasi dari MS. Office dengan materi template presentasi dengan slide master, hyperlink, menyisipkan banyak foto, menyisipkan video dari You Tube dan Pembuatan Soal dengan Triger; (4) Program aplikasi MS. Publiser dengan materi template MS Pubhliser, menumenu Publisher, Mengaktifkan MS. Publisher, membuat file publisher, menyimpanfilepublisher, membuka file publisher, membuat kalender dan kartu nama; (5) Internet sebagai Media Pembelajaran; dan (6) Penyuntingan slide; Untuk mata diklat Aplikasi Penilaian Kurikulum 2013 dilakukan praktek dengan penugasan berkelompok. Masing-masing kelompok membuat aplikasi penilaian untuk memberikan deskripsi pada sikap, pengetahuan dan ketrampilan serta untuk pelaporan hasil belajar peserta didik secara keseluruhan.

Aspek ketrampilan peserta dapat dilihat dari keterampilan peserta dalam menyelesaikan tugas-tugas praktik dalam 6 mata diklat. Untuk mata diklat Aplikasi Penilaian Kurikulum 2013. Hasil penilaian keterampilan peserta diklat saat praktik baik secara 
individu menunjukan hasil sangat baik dengan rata-rata nilai 86,25 dan praktik secara kelompok menunjukkan hasil baik dengan rata-rata 85,11.

\section{PENUTUP}

\section{Simpulan}

Berdasarkan hasil dan pembahasan didapatkan hasil penelitian sebagai berikut.

a. Kepuasan peserta diklat (reaction) terhadap aspek edukatif penyelenggaraan Diklat Multimedia dalam kategori baik dengan nilai 87,62

b. Kepuasan peserta diklat (reaction) terhadap aspek fasilitas dalam kategori baik dengan nilai 87,63

c. Kepuasan peserta diklat (reaction) terhadap aspek pelayanan dalam kategori baik dengan nilai rata-rata 89,38

d. Hasil belajar peserta diklat (learning) pada aspek sikap dalam kategori sangat baik dengan rata-rata 88,54 , aspek pengetahuan dalam kategori baik dengan rata-rata 82,07 dan pada aspek keterampilan dalam kategori sangat baik dengan rata-rata 85,68 .

\section{Rekomendasi}

Agar kepuasan (reaction) peserta pada penyelenggaraan diklat dapat masuk dalam kategori baik maka rekomendasi untuk penyelenggara kediklatan Ballai Diklat Keagamaan Semarang, yaitu:

a. Frekuensi kegiatan ekstrakurikuler perlu ditambah dengan mengadakan kegiatan olahraga ataupun ditambah dengan adanya kegiatan untuk seni.

b. Mengatur menu konsumsi agar lebih bervariasi dan

c. Penggunaam software yang sama antara peserta diklat dan widyaiswara

d. Peningkatan hasil belajar (learning) peserta diklat dapat dilakukan dengan menggunakan metode tutor sebaya.

e. Evaluasi pelaksanaan diklat juga perlu dilakukan untuk level 3 (perilaku kerja) dan 4 (dampak) melalui kegiatan evaluasi pasca diklat. 


\section{DAFTAR PUSTAKA}

Arikunto, Suharsimi dan Cepi Safrudin Abdul Jabar. 2009. Evaluasi Program Pendidikan. Jakarta: Bumi Aksara.

Griffin, P \& Nix.P. 1991. Educational Assestment and Reporting. Sydney: Harcout Brace Javanovich Publiser.

Hamalik. 2006. Proses Belajar Mengajar. Jakarta: Penerbit Bumi Aksara.

Keputusan Memteri Agama Nomor 345 Tahun 2004 tentang Organisasi dan Tata Kerja Balai Diklat Keagamaan Semarang

Kirkpatrick, Donald L., and James D. Kirkpatrick. 2006. Evaluating Training Programs: The Four Levels. 3rd ed. San Francisco,CA: Berrett-Koehler Publishers.

Nainggolan. 2007. Pembinaan Pegawai Negeri Sipil. Jakarta: PT. Perca.

Peraturan Menteri Agama Nomor 75 Tahun 2015 Tentang Penyelenggaraan Pendidikan dan Pelatihan Pegawai pada Kementerian Agama

Peraturan Pemerintah Republik Indonesia Nomor 101 Tahun 2000 tentang Diklat Pegawai Negeri Sipil

Sopacua, E., \& Budijanto, D. 2007. Evaluasi 4 Tahap Dari Kirkpatrick Sebagai Alat Dalam Evaluasi Pasca Pelatihan. Buletin Penelitian Sistem Kesehatan. Vol 10 - No. 4 Oktober. ejournal.litbang.depkes.go.id/ index.php/hsr/article/view/1764/2618

Stark \& Thomas. 1994. http://www.businessballs.com/ kirkpatricklearningevaluationmodel.htm. diambil pada tanggal 23 November 2016

Stufflebeam, D.L \& Shunkfield, A.J. 1985. Systematic Evaluation. Needham Heights: Simon \& Schuster Costum Publishing

Sudjana, Nana. 2005. Penilaian Proses Hasil Belajar Mengajar. Bandung: Remaja Rosdakarya.

Sugiono. 2001. Metode Penelitian Administrasi. Cet. VIII; Bandung: Alfabeta Wursanto. 1994. Manajemen Kepegawaian I. Yogyakarta:Kanisius.

Undang-undang Nomor 5 Tahun 2014 Tentang Aparatur Sipil Negara 